\title{
The Bronze Age in SE Sweden Evidence of Long-Distance Travel and Advanced Sun Cult
}

\author{
Nils-Axel Mörner ${ }^{1} \&$ Bob G. Lind ${ }^{1}$ \\ ${ }^{1}$ Paleogeophysics \& Geodynamics, Stockholm, Sweden \\ ${ }^{2}$ Archaeoastronomy, Malmö, Sweden \\ Correspondence: Nils-Axel Mörner, Paleogeophysics \& Geodynamics, Stockholm, Sweden. E-mail: \\ morner@pog.nu
}

Received: November 26, 2012 Accepted: December 18, 2012 Online Published: January 4, 2013

doi:10.5539/jgg.v5n1p78

URL: http://dx.doi.org/10.5539/jgg.v5n1p78

\begin{abstract}
The Bronze Age of Scandinavia (1750-500 BC) is characterized by the sudden appearance of bronze objects in Scandinavia, the sudden mass appearance of amber in Mycenaean graves, and the beginning of bedrock carvings of huge ships. We take this to indicate that people from the east Mediterranean arrived to Sweden on big ships over the Atlantic, carrying bronze objects from the south, which they traded for amber occurring in SE Sweden in the Ravlunda-Vitemölla-Kivik area. Those visitors left strong cultural imprints as recorded by pictures and objects found in SE Sweden. This seems to indicate that the visits had grown to the establishment of a trading centre. The Bronze Age of Österlen (the SE part of Sweden) is also characterized by a strong Sun cult recorded by stone monuments built to record the annual motions of the Sun, and rock carvings that exhibit strict alignments to the annual motions of the Sun. Ales Stones, dated at about $800 \mathrm{BC}$, is a remarkable monument in the form of a $67 \mathrm{~m}$ long stone-ship. It records the four main solar turning points of the year, the 12 months of the year, each month covering 30 days, except for month 7 which had 35 days (making a full year of 365 days), and the time of the day at 16 points representing 1.5 hour. Ales Stones are built after the same basic geometry as Stonehenge in England.
\end{abstract}

Keywords: travel and trading, Atlantic voyages, trading station in SE Sweden, archaeoastronomical calendar, Ales Stones, Bronze Age, SE Sweden, Österlen

\section{Introduction}

The SE part of Sweden, known as "Österlen", is unusually rich in remains from the Bronze Age. Some of those remains are only found in this region and seem to have a direct influence from Mycenaean, Minoan and Phoenician people (Mörner \& Lind, 2010, 2012; Lind \& Mörner, 2010).

Österlen was also the centre of a strong Sun cult in the Bronze Age. This is evident from huge stone calendars (Lind, 2004; Lind \& Mörner, 2010; Mörner \& Lind, 2012) and the fact that the rock carvings exhibit strict solar alignments (Mörner, 2012a).

These two topics will be the main points of the present paper, ending with a concluding sequence of event characterizing the Bronze Age in SE Sweden (Österlen).

The geographic location is given in Figure 1. The main trading centre was located in the area of Ravlunda (where the amber was to be found), Heimdall's Stones (a stone calendar) and the Kivik Grave (with remarkable rock carvings on the stones of the sarcophagus). The main stone calendars are Ales Stones, Stenhed and Heimdall's Stones. The rock carvings occur in the Järrestad-Simrishamn-Braantevik area. The earthquake seems to have been centred in the Brantevik area with fractured rock carvings, at least, over an area of $5 \times 5 \mathrm{~km}$. The quartzite blocks in the stem and stern of Ales Stones must originate from the Brantevika area and most probably from the Brante Träsk quarry. 


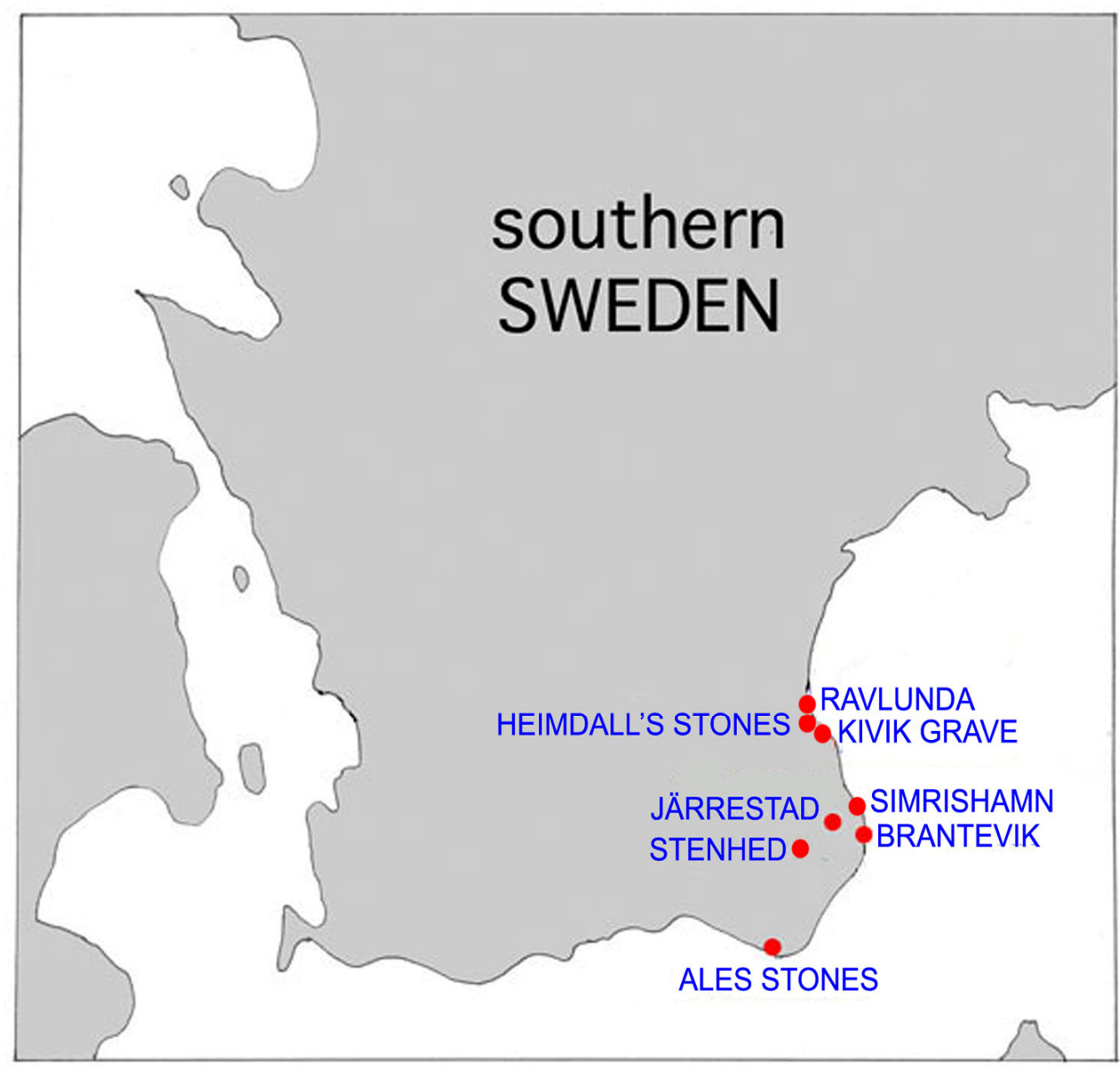

Figure 1. South Sweden with location of the sites in "Österlen" mentioned in the text

\section{Travel and Trading}

The Bronze Age started around 3000-3300 BC in the East Mediterranean and the Middle East, around 2100 BC in the British Islands and at about $1750 \mathrm{BC}$ in Scandinavia and north-central Europe. The differences in time indicate a stepwise evolution between absence of trading and travel and opening of travel and trading (Mörner \& Lind, 2010, 2011, 2012).

The onset of the Bronze Age in Scandinavia is marked by a sequence of simultaneous events, viz. the following 3 events (Figure 2):

(1) the sudden appearance of bronze objects in Scandinavia

(2) the sudden mass appearance of amber in Mycenaean graves in Greece

(3) the onset of the carving of huge ships into the bedrock

We combined those facts into a unified picture, proposing that Mycenaean people had arrived in huge ships over the sea loaded with bronze objects, which they traded with amber (Mörner \& Lind, 2008, 2010, 2011, 2012; Lind \& Mörner, 2010). Amber was present at Ravlunda in SE Sweden. The name "ravlunda" refers to amber, as "rav" is the old word for amber and still the Danish word for amber. Amber is regularly washed ashore at Ravlunda; in the past as well as today. In older days, it seems even to have occurred in the coastal sedimentary beds, however (Lind \& Mörner, 2012). 

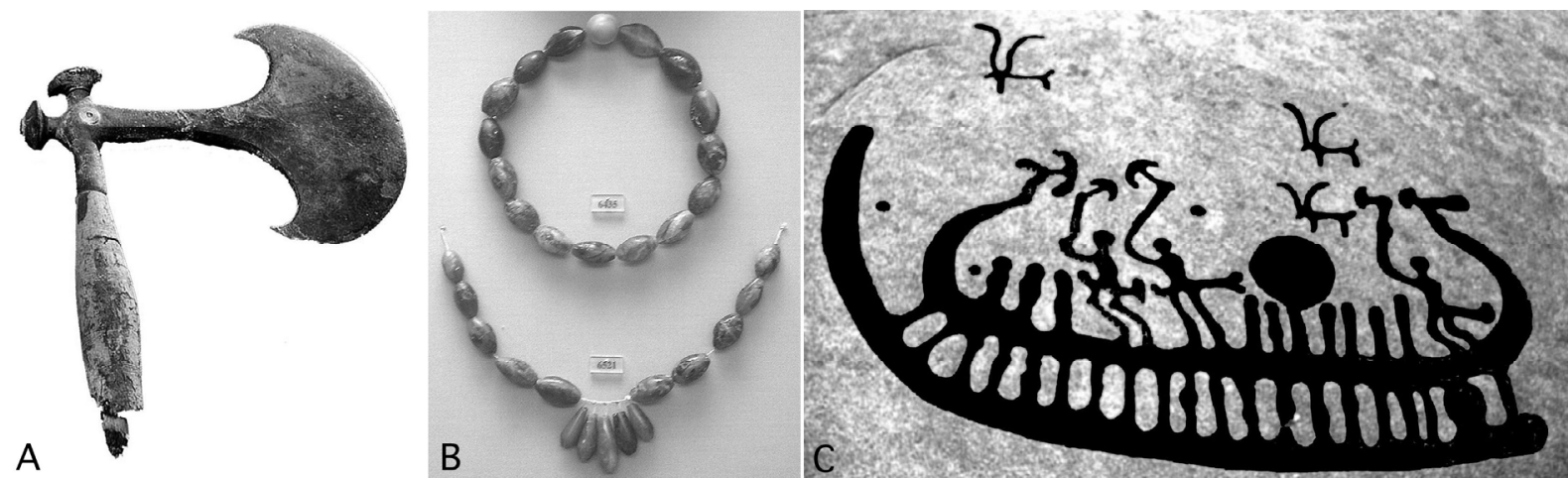

Figure 2. At about $1750 \mathrm{BC}$, the onset of the Bronze Age in Scandinavia, three things happened at the same time (Mörner \& Lind, 2010, 2012): Bronze from the Mediterranean appeared in Scandinavia (A), amber from the Baltic (probably Ravlunda) started to appear in masses in Mycenaean graves (B), and pictures of huge ships started to be cut into the bedrock and bronze objects in Scandinavia (C)

In the Ravlunda-Kivik area, the Mycenaean visitors seem to have established a real trading post (Mörner \& Lind, 2008, 2010). The evidence for a strong Mediterranean influence is plentiful (Mörner \& Lind, 2010; Lind \& Mörner, 2010; Mörner \& Lind, 2012). This is not a new observation, but was already proposed in the late $19^{\text {th }}$ century by Nilsson (e.g. 1875). Nilsson suggested that the visitors were Phoenician. We propose that the first visitors were Mycenaean and that this happened in the early Bronze Age, also marking the onset of Scandinavian Bronze Age (points 1-3, above). In the Late Bronze Age, the Phoenicians followed (Lind \& Mörner, 2010).

The objects, pictures and ornaments with a clear Mediterranean provenience found in southeast Sweden (Österlen) have been discussed in previous papers (Mörner et al., 2009; Lind \& Mörner, 2010; Mörner \& Lind, 2010, 2011, 2012). A few examples will be given here (Figures 3-5).

On one of the stones of the sarcophagus of the Kivik grave, there is a picture of a war chariot (Figure 2a), which is more or less identical to those used in Mycenae (Marstrander, 1963; Kristensen, 2004). Besides, the war chariot is of great interest as a sign of the Indo-Europeans (Beckwith, 2009), appearing in the Mycenaean Greece at about $1600-1700 \mathrm{BC}$.

The spiral ornament provides another linkage between SE Sweden (Österlen) and Greece (Figure 3b); the quadruple on a bronze jewellery found in a grave in SE Sweden, is identical to that of a pendant of bronze from the necropolis at Asini in Greece, both dated at about 1600-1700 BC (Lind \& Mörner, 2010).

The omega sign belongs the East Mediterranean and the Middle East. It occurs in Egypt and Mesopotamia prior to the Greek letter omega. In Österlen, there are 3 omega pictures (Figure 3c); two in the Kivik grave and one carved into one of the stones of Heimdall's Stones (Mörner et al., 2009; Lind \& Mörner, 2012; Mörner \& Lind, 2012).

Our interpretation is supported by the finding of the "Boy with the amber necklace" close to Stonehenge (Evens et al., 2006), old harbours along the Portuguese coast (Mörner \& Lind, 2012) and the fact that Stonehenge in England and Ales Stones in Sweden are built with the same basic geometry (Mörner \& Lind, 2012b).

Bronze is an alloy of tin and cupper. In the Mediterranean there is a lot of cupper, but a general shortage of tin. In Cornwall in southeast England, there is much tin and it was used from late Neolithic time, setting the onset of the local Bronze Age in Great Britain at about 2100 BC. 


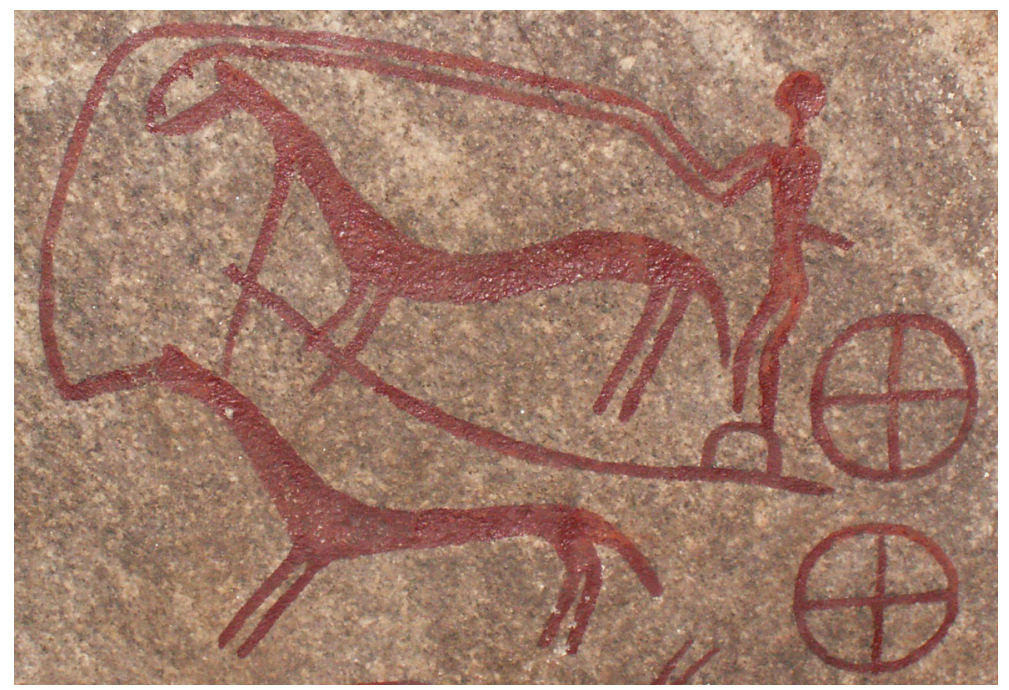

A
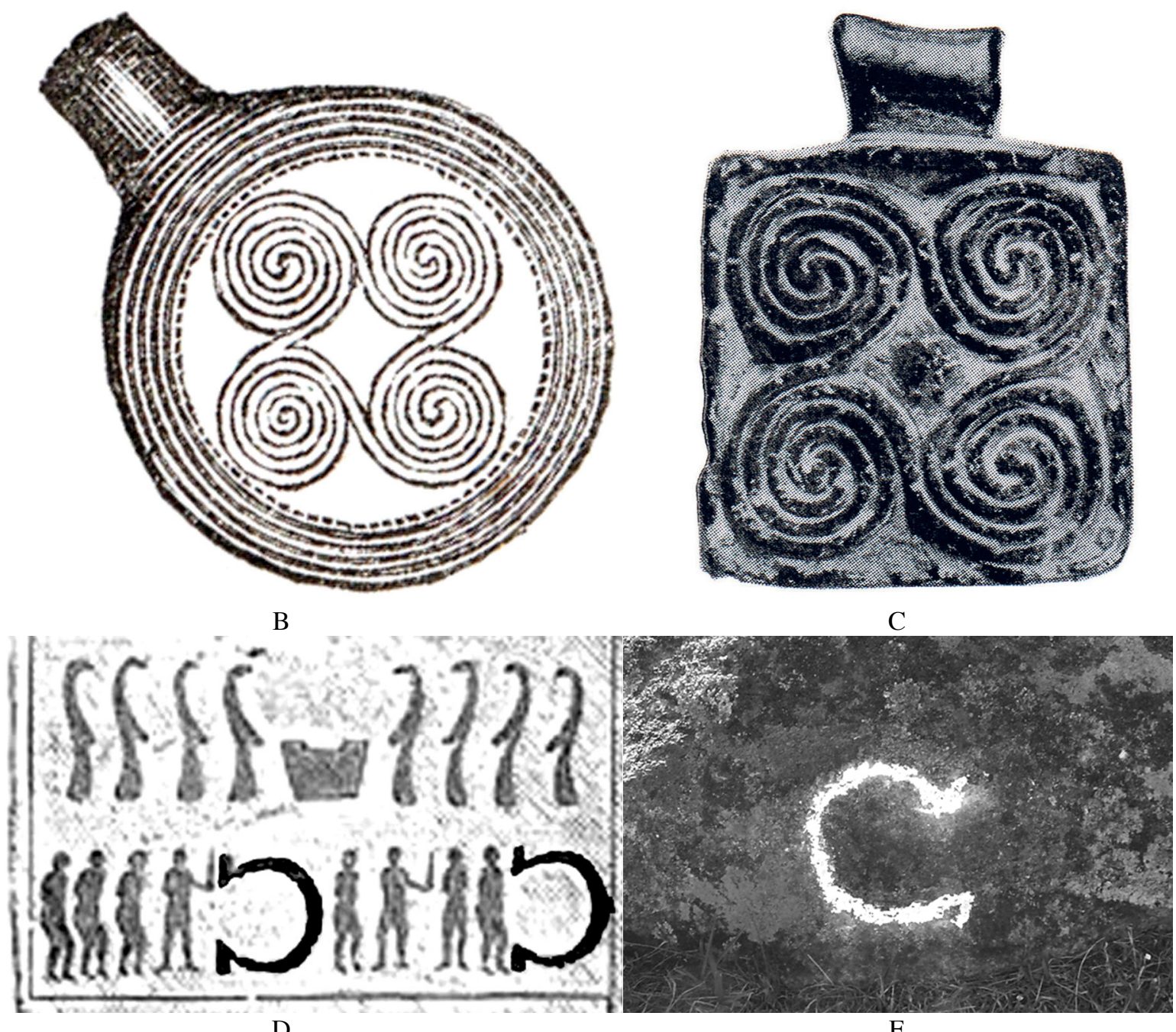

Figure 3. (A) the war chariot in the Kivik grave; (B) the spiral ornament from Sweden and Greece (C); Omega signs from the Kivik grave (D) and Heimdall's Stones (E). All indicating a close cultural linkage between Österlen and Mycenae 
In Sweden, there is a lot of cupper, and the question was if this was used for our Scandinavian bronze objects. An international team has been working on the identification of the metals used in Scandinavian bronze objects. It was recently revealed (Ling, 2012) that the cupper in all Scandinavian Bronze Age tools originates from the Mediterranean; viz. from quarries in Cuprous, Sicily and Spain. Consequently, all the bronze or cupper used in our bronze object has been imported. This lends strong support of our proposition of a direct travel and trading over the sea as given in points 1-3 above (Mörner \& Lind, 2010, 2011,2012a) and other sites in the Simrishamn area.

\section{The Sun Cult, Solar Motions and Time}

It is an old and generally accepted idea that the Bronze Age was a period sun cult with the Sun as a central deity (e.g. Montelius, 1911; Almgren, 1927; Bröndsted, 1938). Therefore, it is by no means surprising that we find monuments and rock carvings that have a very strict solar alignment. This is the case with the circular monument of Heimdall's Stones (Mörner et al., 2009), the gigantic stone-ship of Ales Stones (Mörner \& Lind, 2010; Mörner \& Lind, 2012b), the big graves of Brantarör (Lind, 2012) and the individual rock carvings at Järrestad (Mörner, 2012).

Heimdall's Stones consist of circular stone settings (Mörner et al., 2009; Lind \& Mörner, 2010). They are arraneged with strict alignments to the sunrise and sunset at summer solstice, the sunrise and sunset at winter solstice, and the sunrise and sunset at the equinoxes, implying that the user had a perfect control of the seasonal changes of the year. There are also stones in strict north-south alignment, implying that they could also obtain information of the time of the day. The stones marking the north have the form of a phallus, indicating that the phallus cult (imported from the Mediterranean) was also strong (Mörner \& Lind, 2010). The individual stones have numerous cup marks and carvings of an omega-sign, a delta-sign, a serpent, two fishes and sun discs (Mörner et al., 2009). The floor of the monument and the old land surface of the surrounding area are covered by eolian sand dated at about 500-600 BC by bracketing C14-dates of $467 \pm 45$ and $604 \pm 126$ cal. years BC (Mörner et al., 2009).

Ales Stones is a $67 \mathrm{~m}$ long stone-ship with impressive setting at a $40 \mathrm{~m}$ high moraine ridge at Kåseberga. It consists of 57 big blocks; 55 crystalline erratic boulders gathered from the surrounding moraine surfaces and 2 huge block of quartzite transported from Brantevik, $30 \mathrm{~km}$ to the northeast (Bergström, 1990; Mörner in Lind, 2012). Ales Stones is, indeed, a quite remarkable arkaeoastronomical monument (Lind, 2004). It records the annual solar motions, the monthly changes and the time of the day (Lind \& Mörner, 2012; Mörner \& Lind, 2012b). Ales Stones are built so that, seen from the centre, the sun rises over the stern stone at winter solstice and the sun sets over the stem stone at summer solstice. The sun rises at summer solstice between the two stones marking the mid-ship in NE and sun sets at winter solstice between the opposite stones in SW. Similarly, the sunrise and sunset at equinoxes occur precisely over the $12^{\text {th }}$ stones marking the $\mathrm{E}-\mathrm{W}$ alignment. These six main solar events are recorded in Figure 4 (from Mörner \& Lind, 2012b). The stone arrangements also provides a record of the months, all of 30 days of the months except for the $7^{\text {th }}$ month that had 35 days, making a total year of 365 days. The daily motion of the sun (i.e. the shadow from a pole placed in the centre with an inclination to the north of $30^{\circ}$ ) is recorded by 16 stones, each one of which represents a duration of 1.5 hour. A full description is given in Lind (2004) and Lind and Mörner (2010).

Even cup marks on the top of two stones exhibit perfect alignments to the annual motions of the sun (Lind \& Mörner, 2010; Mörner \& Lind, 2012b). This is in full agreement with an age of construction in the Late Bronze Age.

The rise of the sun at winter solstice over the stern stone and the setting of the sun behind the stem stone have, in fact, a small deviation $0.77^{\circ}$ due to the cyclic change of the tilt axis of the earth. It is consistent with a time of erection of about $700 \mathrm{BC}$ (Lind \& Mörner, 2010).

Finally, we recently were able to show that Ales Stones was built after the same basic geometric principles as Stonehenge (Mörner \& Lind, 2012b). 


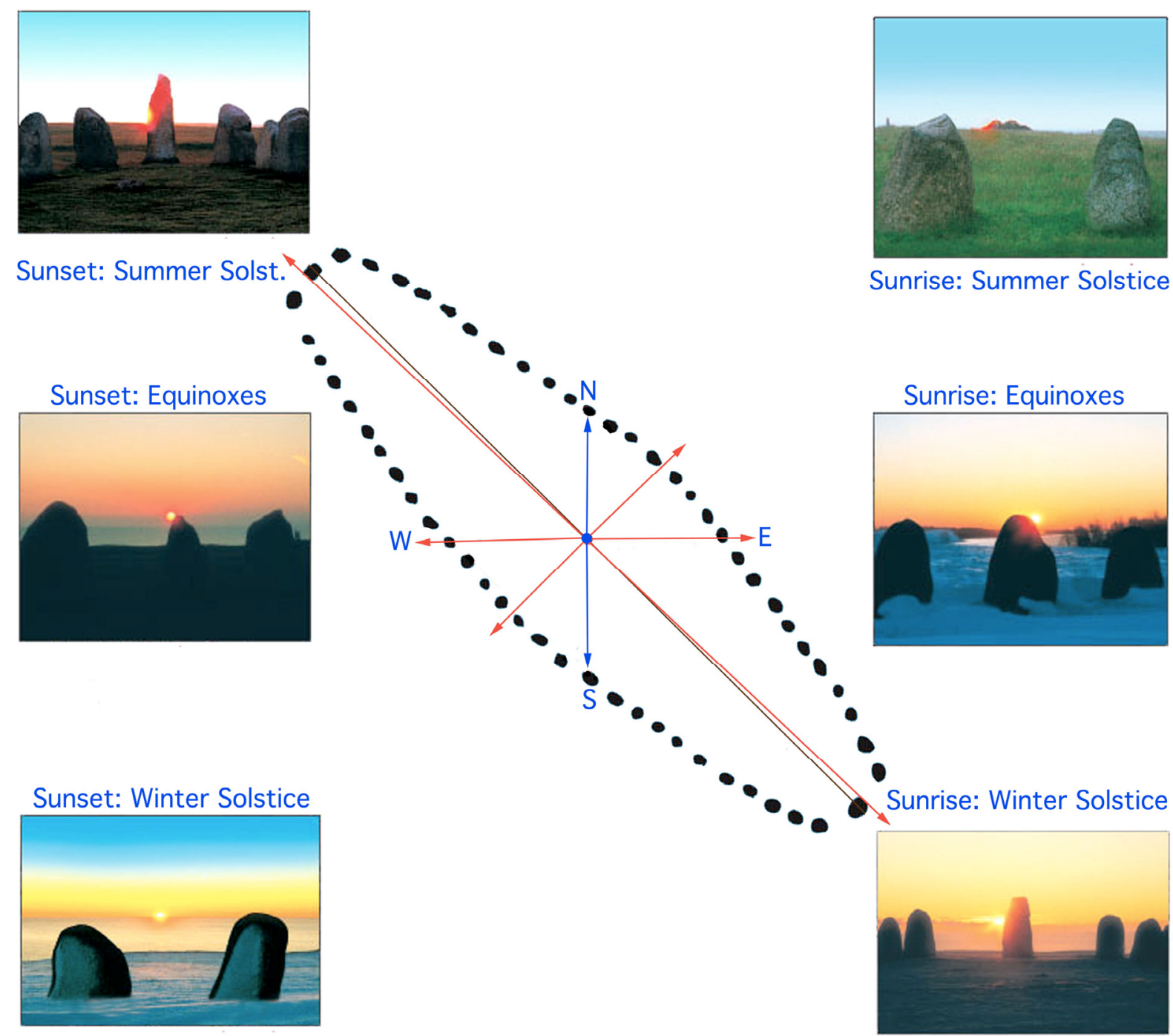

Figure 4. Sunset and sunrise documented at Ales Stones at the six major stages in the annual motion of the sun

(Mörner \& Lind, 2012b)

Finally, we recently were able to show that Ales Stones was built after the same basic geometric principles as Stonehenge (Mörner \& Lind, 2012b).

Stenhed is another stone-ship. It is $50 \mathrm{~m}$ long and located right in the middle of a straight line between Ales Stones and the Kivik grave and it exhibits similar solar alignments as Ales stones (Lind, 2004).

Recently, Lind (2012) has shown that the Bronze Age graves at Brantevik known as Brantarör are also located with respect to the solar motion; at summer solstice the sun rises right over the northern grave if viewed from the southern grave, and at winter solstice the sun sets right over the southern grave if viewed from the northern grave.

Consequently, we have 4 stone monuments in Österlen, which exhibit strict orientations with respect to suns annular motion over the sky. In addition to this, we also have the Haväng dolmen from the Late Neolithic, which is built and oriented with respect to the solar motions.

There are many rock carvings from the Bronze Age in Österlen. At Järrestad (Figure 5). there are so many individual pictures that meaningful statistical analyses of their distribution could be obtained (Mörner, 2012a). Sharp Gaussian distribution peaks were obtained for pictures of feet, shoes and ships. There are 69 feet and 11 pairs of feet; $75 \%$ of them pointing to the sunrise at winter solstice and $15 \%$ pointing to the sunset at summer solstice. There are 45 shoes and 19 pairs of shoes; $95.3 \%$ of them pointing to the sunrise at winter solstice. There 
are 20 big ships, all of them pointing to the sunset at winter solstice. Singular pictures of a dancer, a serpent and a spiral also exhibit strict solar alignments (op.cit.).

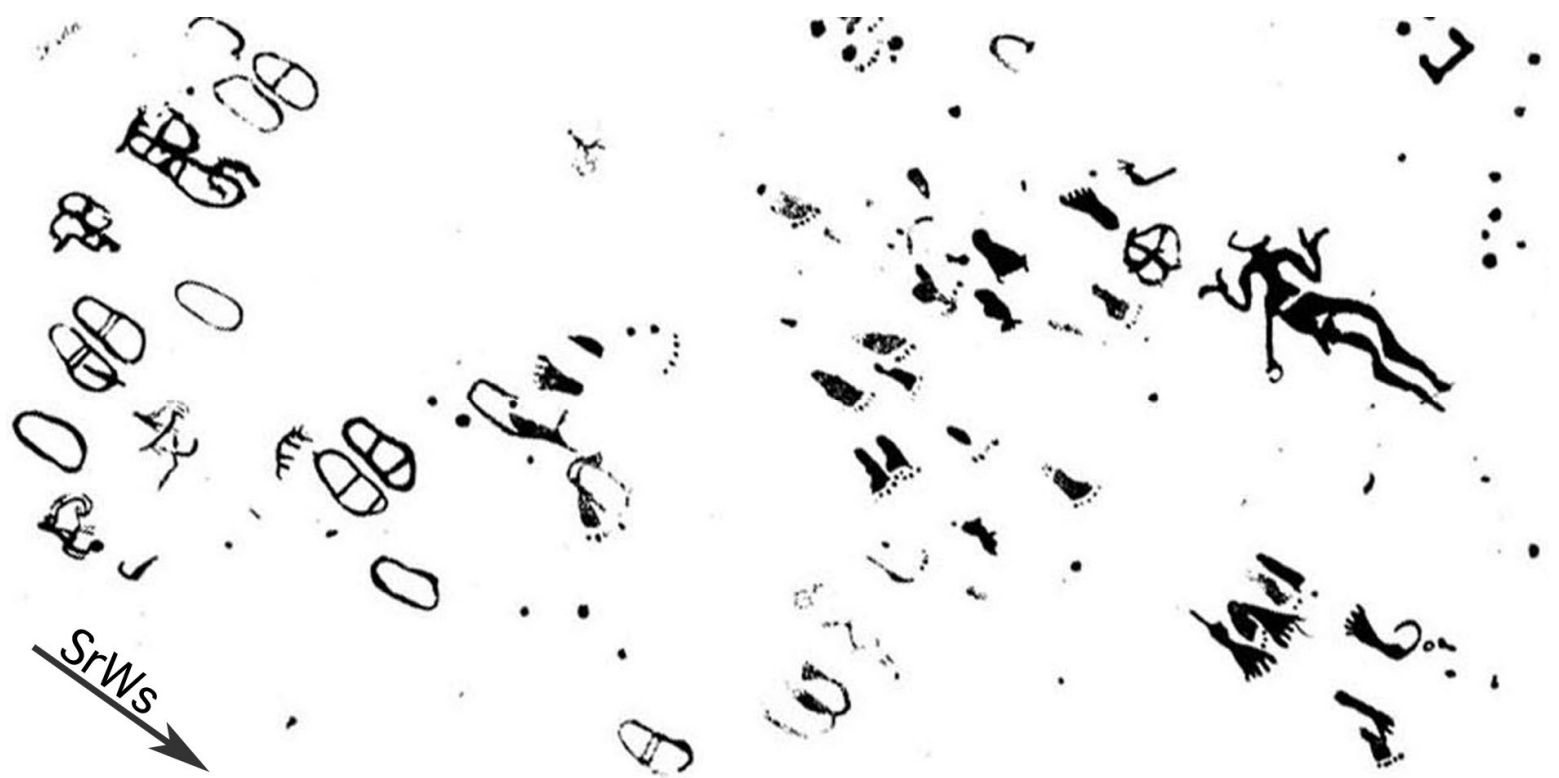

Figure 5. A segment of the Järrestad rock carving. The pictures show a clear and strict alignment to the annual motion of the Sun (Mörner, 2012a). The dancer, 75\% of the feet and 95.3\% of the shoes point to the sunrise at winter solstice (SrWs, as arrow points). Obviously, this solar turning point (the return of light) was the major cultural event of the year

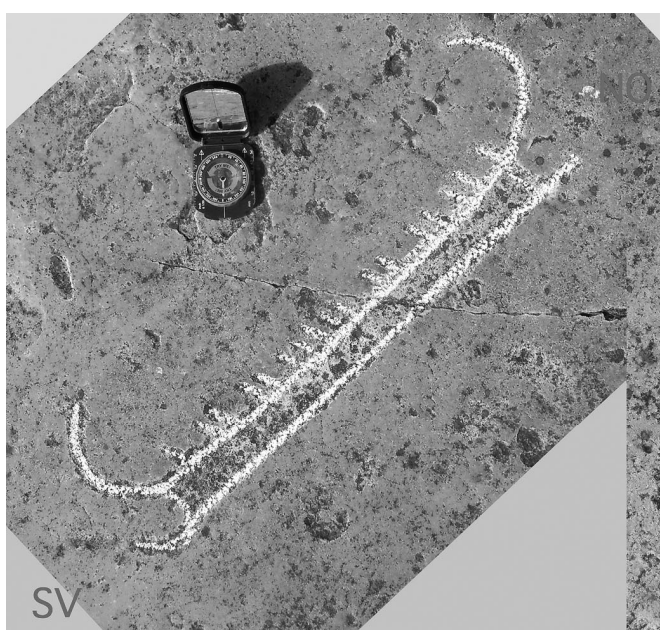

A

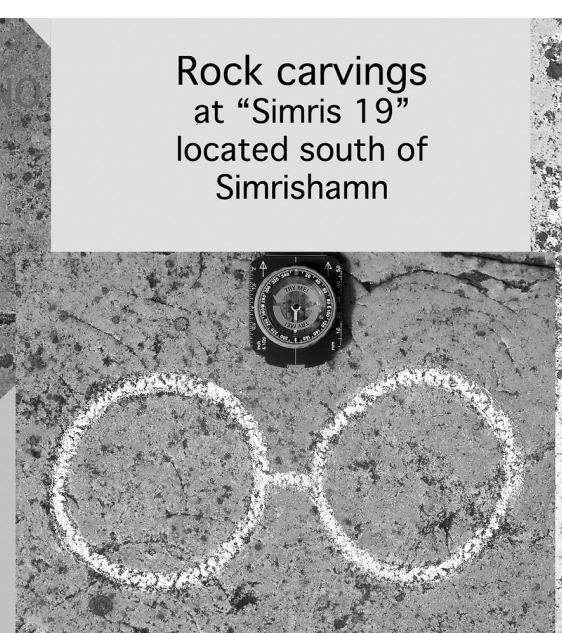

B

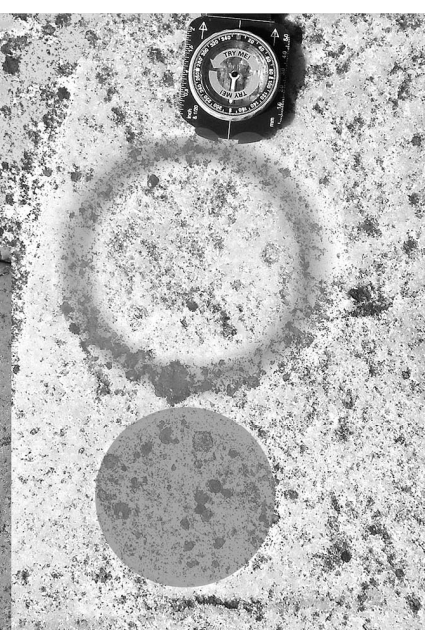

$\mathrm{C}$

Figure 6. Rock carvings at Simris 19. (A) a big ship pointing to the sunset at winter solstice. (B) two equal solar discs connected by a line representing the day and night symmetry at spring and autumn equinoxes in W-E alignments. (C) the sun and the moon at the eclipse $1460 \mathrm{BC}$ (as identified by Henriksson)

This summer, we investigated other sites in Österlen and recorded numerous other carvings strictly oriented with respect to the solar motions. At Gislöv, there is a sun-wheel with the central cross-lines in N-S and E-W. At Simrislund North, there are three ships, all pointing to the sunset at winter solstice (i.e. just as they do in Järrestad; Mörner, 2012), and a geometric picture, oriented in E-W and N-S. Site Simris 19 (in Simrislund) has several objects of interest (Figure 6); several ships pointing towards the sunset at winter solstice, and two equal circles connected with a line in E-W, suggesting a reference to the equal solar situation of the length of day and night, and of sunrises and sunsets at the spring and autumn equinoxes. There is also an open solar disc circle 
with a smaller filled circle right below in the south. It is tempting to think in terms of a picture of an ancient eclipse with the moon approaching the sun. Indeed, this seems to be the case as astronomer Göran Henriksson has been able to calculate that it must depict an eclipse at $99.7 \%$ occurring on the 28 of May in the year $1460 \mathrm{BC}$ at 15.14 o'clock local solar time (Henriksson, personal communication, May 24, 2012).

\section{Sequence of Event in the Late Bronze Age}

At about 500-600 BC climate changes from the warm and dry Sub-Boreal period to the cool and wet Sub-Atlantic period. This change coinsides with the change from Bronze Age to Iron Age in Scandinavia. The transition is characterized by short period (in the order of 50-60 years) of exceptionally warm and dry conditions, generating extensive sand drift and a major hiatus in the peat growth (Mörner, 1999). We have dated this sand drift also locally at Heimdall's Stones (Mörner et al., 2009) and Ales Stones (this paper), because in both cases the monuments were erected prior to this event of general sand drift in the period 600-500 BC.

Ales Stones is a calendar from the Late Bronze Age according to us (Lind, 2004; Lind \& Mörner, 2010; Mörner, 2011). According to Söderberg et al. (2012), however, it dates to the period 600-1000 AD, and they claim that there is a date of charcoal from beneath one of the stones. This notion stems from the work of Strömberg, who in 1995 undertook an excavation right beside one of the stone (known as stone N24). She left two diggers alone to undertake the excavation by themselves. According to a personal statement by one of the diggers in 2012, they dug down the side of the stone and stopped some $60-70 \mathrm{~cm}$ down where they reached the stone-foot (i.e. the small stones pressed down around the big block). They collected some "black material" in a plastic bag, later handed over to Strömberg. On this bag, recovered by us in 2012 at the Institute of Paleoosteology at Stockholm University, it is clearly written that the material was found "beside" the block; i.e by no means "beneath" the block (Mörner et al., 2012). Strömberg (1997) gave a very vague description, whilst Söderberg et al. (2012) firmly stated that it was taken from beneath the block (they even moved the X-sign by Strömberg beside the stone, to a point-sign on top of the stone implying a position beneath it). Consequently, we can discard the claims by Söderberg et al. (2012) and turn to better means of dating (e.g. Mörner, 2011 and unpublished C14-dates from our 2011 excavation, but here presented in Figure 7).

At our excavation in 2011, we found the imprint of a huge block in the old glacial surface of boulder clay (Mörner, 2011), some $50 \mathrm{~m}$ from the stone-ship itself. The hollow is filled by eolian sand, implying that the block must have been removed before the deposition of the eolian sand, which is likely to have occurred some 500-600 BC (cf. above). If so, Ales Stones must have been erected shortly before this event of sand drift; i.e. in the Late Bronze Age.

At the shore below the monument, just where we expected that the block of quartzite must have been taken ashore, there is a distinct raised beach from the period 1000-700 BC. The surface of the shingly beach material is covered by a habitation layer. Charcoal from this layer was collected in 2009 and dated at $785 \pm 20$ cal. yrs. BC (Lind \& Mörner, 2010). In 2011, we undertook additional excavations, coring and sampling. Six samples were C14-dated. A second sample from the habitation layer was dated at $775 \pm 35 \mathrm{BC}$. It is covered by an eolian sand, the top of which is dated by another habitation layer at $385 \pm 35 \mathrm{BC}$ (Figure 6). This means that the phase of eolian sand drift must be younger than about $750 \mathrm{BC}$ and older than about $400 \mathrm{BC}$; i.e. in full agreement with an age of 500-600 BC as given above.

Our stratigraphic records and C14-dates give a clear message; Ales Stones must have been constructed (erected) in the Late Bronze Age, some 800-750 BC. This fits perfectly well with Lind's archaeoastronomical dating at around $700 \mathrm{BC}$, judging from the small deviation is present solar alignment to the stem and stern stones (Lind \& Mörner, 2012).

Figire 7 gives the general stratigraphy of the shore cliff at Ales Stone (Lind \& Mörner, 2010; Mörner, 2011). 


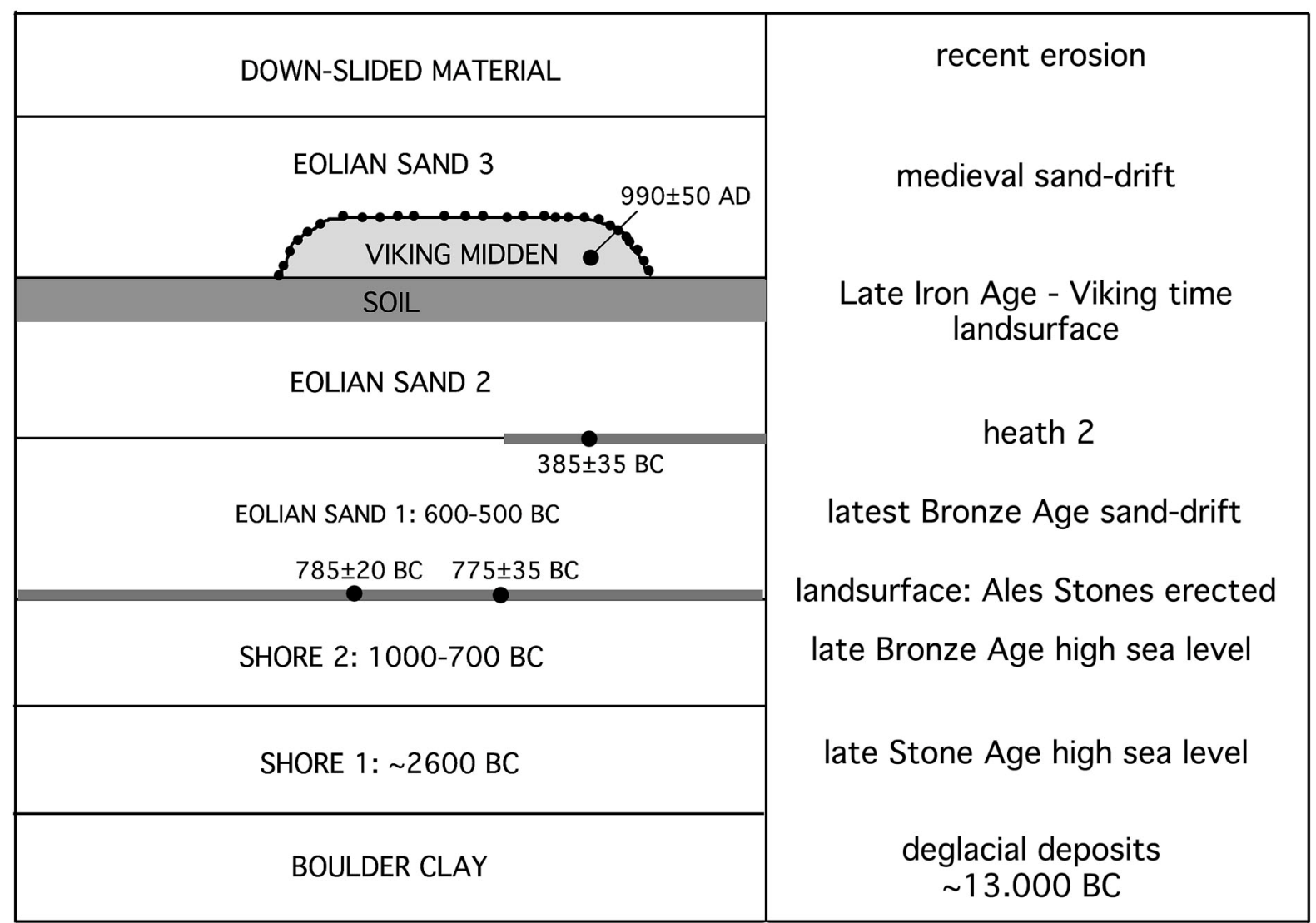

Figure 7. Stratigraphy and chronology of the coastal cliff section at Kåseberga just below the monument of Ales Stones and where the quartzite blocks from Brantevik are supposed to have been take ashore (Lind \& Mörner, 2010; Mörner, 2011). The erection of the stone-ship of Ales Stones must pre-dates the eolian sand drift at 600-500 BC (Mörner, 2011)

At Brantevik, Lind recently revealed that the graves of Brantarör were placed in a strict solar alignment (Lind, 2012). This provides a new cultural linkage between Brantevik and Ales Stones, besides the blocks of quartzite now included in the Ales Stones monument and once collected from the Brantevik area (e.g. Mörner in Lind, 2012).

A picture from 1777 (Lind, 2012) shows that the main grave of Brantarör was surrounded by about 60 blocks; obviously flat and cut blocks of quartzite. Besides, there was a central sarcophagus of at least 12 big and flat blocks of quartzite. All those blocks call for a stone industry and quarry (Mörner, 2012b).

An urn taken from the centre of the grave in 1767 and kept in the family since then was assigned an age of 800-500 BC (E. Jonsson in Lind, 2012), indicating that the graves are from the Late Bronze Age, in full agreement with the finding of a bronze sward and a solar sign in the sarcophagus.

This summer we found an ancient quartzite quarry in Brantevik (Figure 8). Large and flat pieces of rock have been fractured off and transported away. This is surely the result of human activity. In a depression in the quarry, the quarried rock surface is now covered by $40-50 \mathrm{~cm}$ of peat indicating that the quarrying is ancient and, at least, a couple of millennia old. 


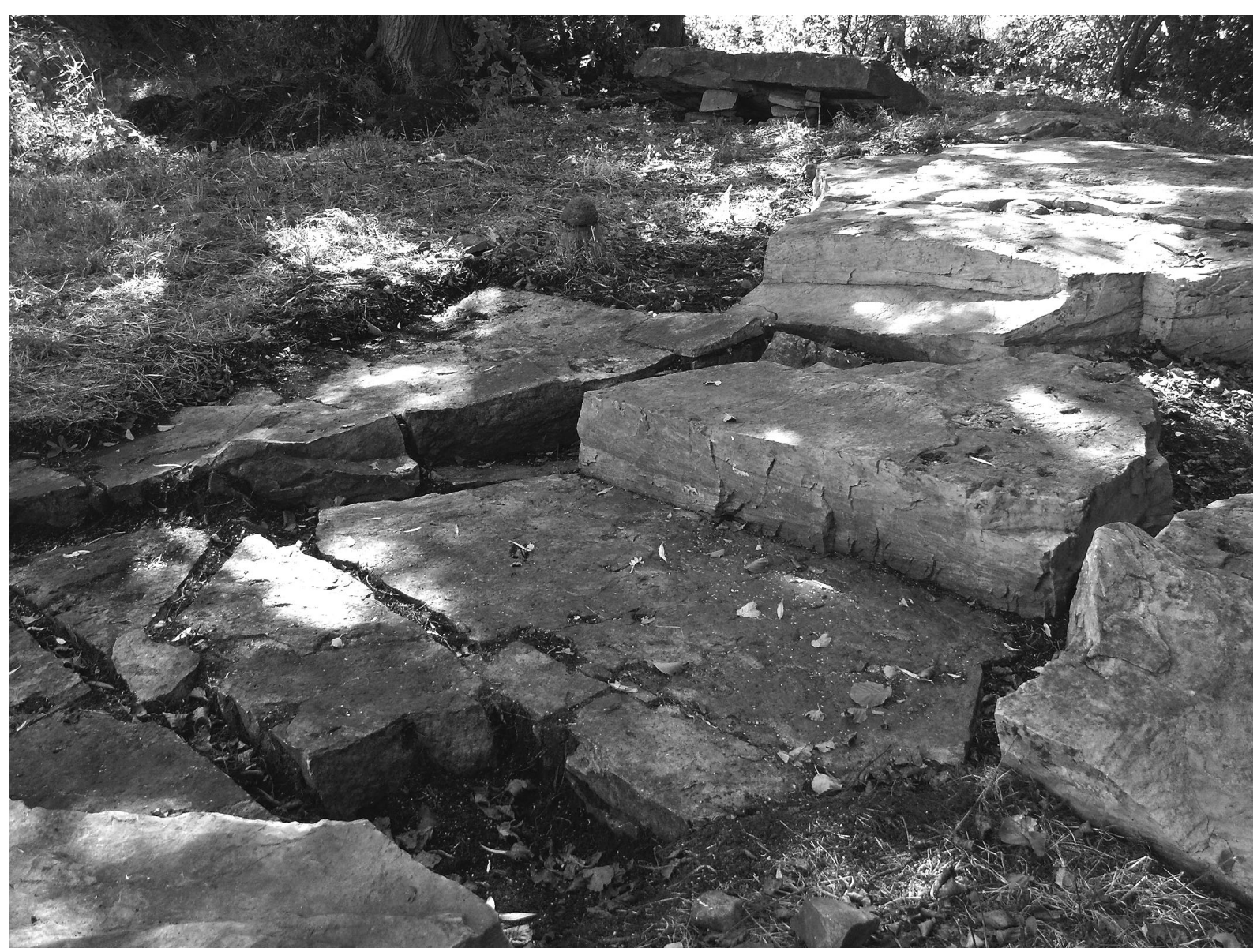

Figure 8. The quarry at Brante Träsk in Brantevik (Mörner, 2012b). The bedrock is heavily fractured. Large blocks have been fractured off and transported away. In the background, there is a big block chocked up by people into an inclined position

The fine structure (i.e. grain size and bedding) of the quartzite at this site is strikingly similar to that of the blocks now standing in Ales Stones. We, therefore, believe that we have found the actual quarry of those stones. It is only in the Brantevik area that the quartzite exhibits a strong similarity to that of the four blocks in Ales Stones (the two huge block standing in the stem and stern of the skip plus 2 minor blocks). Therefore, the provenience of the blocks has earlier been suggested as being Brantevik (Bergsten, 1990; Mörner \& Lind, 2012). Now, we are confident that we have found the very quarry itself. From this quarry, there is about $400 \mathrm{~m}$ downhill to a small natural harbour which existed at Brantevik in the period 1000-700 BC (Mörner \& Lind, 2012). From there, the blocks are likely to have been transported by ships or rafts for $30 \mathrm{~km}$ to the shore at Kåseberga (Bergström, 1990; Lind \& Mörner, 2010). At the assumed landing place, we have the cultural layer C14-dated at $785 \pm 20$ and $775 \pm 35 \mathrm{BC}$ (Figure 7).

The quarry, therefore, seems to have been in active operation around $800 \mathrm{BC}$, providing blocks to the sarcophagus of the Brantarör graves, the 60 side stones around the main Brantarör grave, the 4 blocks transported to Ales Stones and the so-called Trollarestenen with an original location some 1-2 km to the west and having a quartzite structure of just the same appearance as that in the quarry.

The quarry has one more secret to reveal, however (Mörner, 2012b). For a trained eye, it is easy to see that the original fracturing must have been generated by seismotectonic forces; i.e. an earthquake, which is likely have had a magnitude of at least 6 on the Richter scale (Mörner, 2012b). The whole bedrock surface was fractured up in detached pieces by a major expansion force (Figure 9). The blocks have very sharp edges and fresh fracture surfaces, indicating a fracturing well after the ice age. The mode of fracturing follows that of other seismotectonic events in Sweden (Mörner, 2003). Coring in the adjacent swamp (a total of 21 cores), suggest that the event took place in the Mid to Late Holocene. For a more precise age determination we have to look at surrounding rock carvings. 


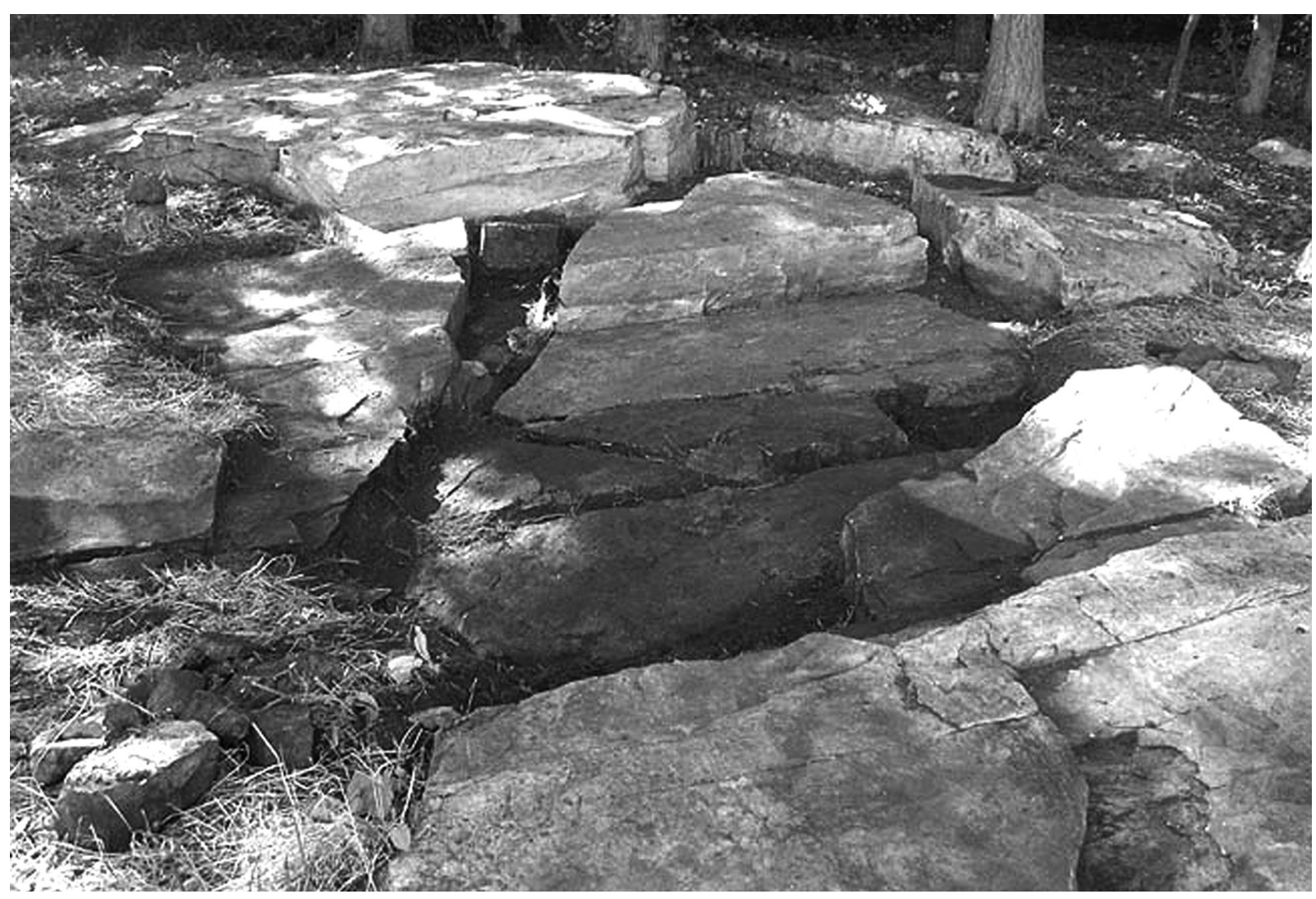

Figure 9. The original fracturing was caused by extensional forces at a major earthquake, generating sharped edged blocks displaced in all directions, something humans would be incapable of doing but what is just what an earthquake of high magnitude may do. Later, people utilized this fracturing and turned the site into a quarry

At Järrestad there is a bedrock surface of quartzite, which is full of rock carvings (Althin, 1955; Mörner, 2012b). A decade ago, it was investigated by Mörner in view of paleo-seismology (Mörner, 2003). He gave the following description (op. cit., p. 268):

"The quartzitic bedrock is polished by glacial processes into a flat 'floor'. Still, this floor is traversed by a dense network of fractures. The glacial erosion was strong and includes lots of crescentric marks, indicating that the ice moved with a very high pressure on the bedrock surface. Therefore, the fractures must be of postglacial age. The rock surface is covered by carvings from the Bronze Age. Some of the pictures are cut by fractures in a manner suggesting that the fractures post-date the pictures."

After the finding of the quarry this summer, we revisited all the sites with rock carvings in the vicinity. Indeed, there are plenty of clear indications that the fracturing post-dates the carving (Mörner, 2012b). This is true for the carvings at Järrestad, Gislöv, Simris 19 and Simrislund (all within a radius of about $5 \mathrm{~km}$ from the quarry). Two examples of the fractured carvings are shown in Figure 10 (additional in Mörner, 2012b). 


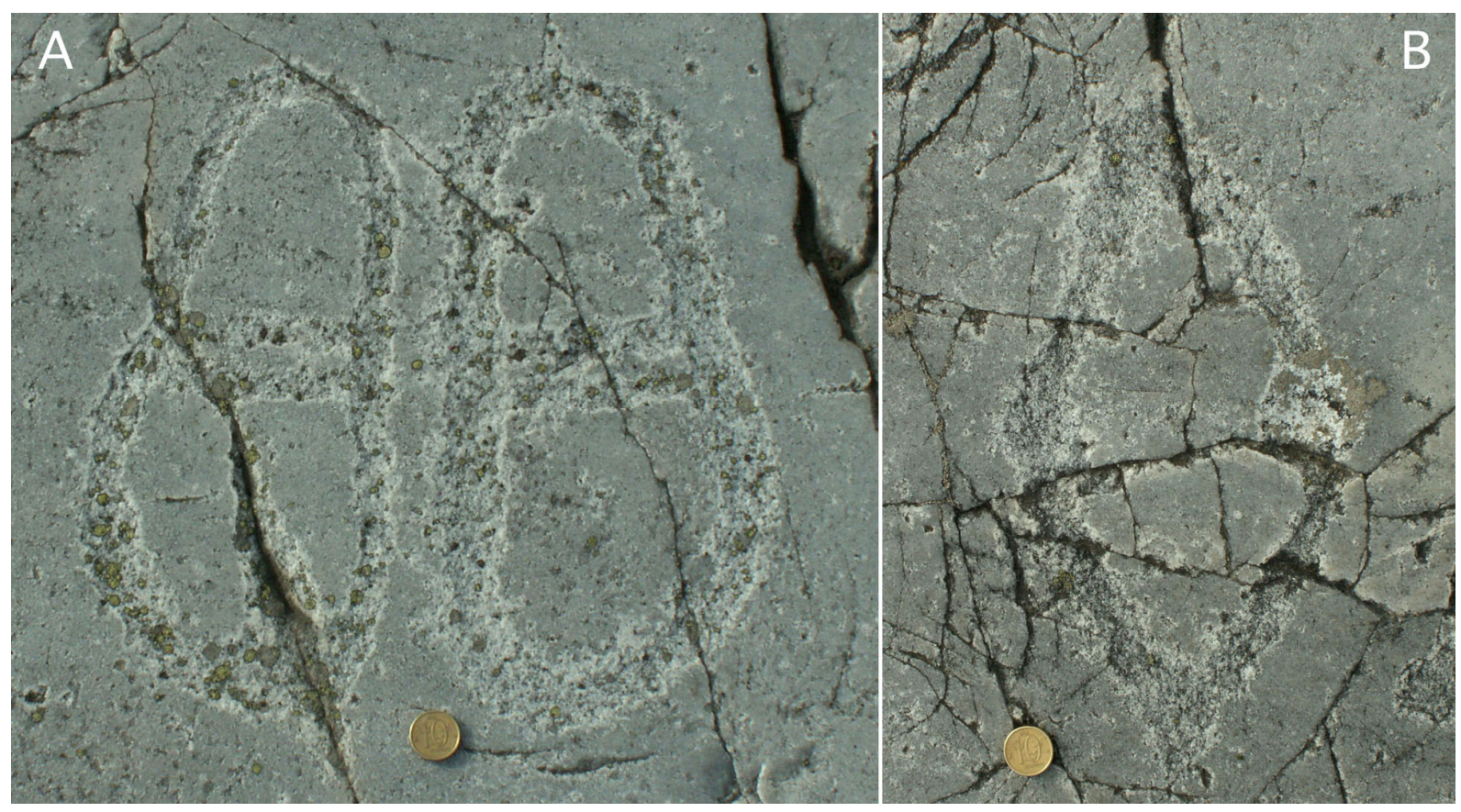

Figure 10. Rock carvings at Järrestad affected by earthquake fracturing in post-carving time (Mörner, 2012b). (A) a fractured pair of shoes. (B) the "sun-ship" deformed by fractures in a way indicating that the fractures must post-date the carving

At the shore, the fracturing seems to pre-date or co-inside with the sea level high-stand at 1000-700 BC (Mörner, 2012b).

Mörner (2012b) therefore assign an age of the earthquake in the order of 1000-800 BC.

\section{Conclusions}

(1) Long-distance travel and trading started with the onset of the Bronze Age at $1750 \mathrm{BC}$. Mycenaean people arrived in big ships over the sea, trading amber for bronze and establishing a trading post in the Vitemölla-Kivik area (Mörner \& Lind, 2010, 2011, 2012a). The traces of visitors from the Mediterranean are plentiful (Mörner \& Lind, 2010; Lind \& Mörner, 2010; Mörner \& Lind, 2012a), including 3 omega signs, picture of the Mycenaean war chariot, the spiral ornament almost identical to that found in Asini in Greece and dated at 1600-1700 BC, and many other things (discussed by Lind \& Mörner, 2010, and Mörner \& Lind, 2012a).

(2) This was 1000 years earlier than the generally assumed first passing of Gibraltar by Phoenician ships at around $700 \mathrm{BC}$. This opens new perspectives and possibilities in view of long-distance travel over the seas (Mörner \& Lind, 2010).

(3) The Bronze Age was a period of very vivid sun culture in Scandinavia. Monuments and rock carvings in SE Sweden exhibit careful and strict alignment to the main stages in the solar motions over the year (Lind \& Mörner, 2010; Mörner, 2012a).

(4) A strong earthquake occurred at about 1000-900 BC (Mörner, 2012b), fracturing the smooth surfaces with rock carvings (Figure 10) and creating very strong seismotectonic deformations at Brante Träsk (Figure 8). This led to the establishment of an "industrial" quarry (Figure 7), from where blocks were taken to the building of the near by Brantarör graves in Brantevik as well as to the far away Ales Stones.

(5) The Brantarör graves were probably built some 800-700 BC. At that time there was a natural harbour in Brantevik (Lind, 2012).

(6) Ales Stones was erected at about 800-750 BC (Figure 7; Lind \& Mörner, 2010; Mörner, 2011; Mörner et al., 2012; this paper). It exhibits a remarkable precision in recording the 6 main stages in the annual motions of the sun (Figure 4), in the sun's monthly (12) and daily (365) motions, and in the hourly changes (in 1.5 hour steps) over the day (Lind, 2004). Besides, its basic geometry was found to be identical to that of Stonehenge (Mörner \& Lind, 2012b). 
(7) The sand drift in the period 600-500 BC offers a useful stratigraphic marker-bed of the end of the Bronze Age (the Iron Age beginning right after the arid phase with sand drift).

The sequence of event characterizing the Bronze Age in SE Sweden (Österlen) can now be summarized as follows:

- 1750 BC: onset of the Bronze Age with the arrival of Mycenaean visitors on big ships.

- 1750-1000 BC: the sun cult flourish in monuments and carvings.

- 1000-800 BC: a major earthquake strikes the area, fracturing the bedrock.

- 800 BC: the quarry at Brante Träsk is in operation for the use in the Brantarör graves and for the transport of the quartzite blocks to Ales Stones.

- 800-750 BC: the monument of Ales Stones is constructed. The sun cult reaches its crescendo in SE Sweden.

- 600-500 BC: a period of aridity and general sand drift, ending the Bronze Age.

\section{References}

Almgren, O. (1927). Hällristningar och kultbruk. Kungl. Vitterhets Historie \& Antikvitets Akademiens Handlingar, 35, 23-31.

Althin, C. A. (1945). Studium zu Bronxezeitlichen Felszeichnungen von Skåne. Gleerups.

Beckwith, C. I. (2009). Empires of the Silk Road. Princeton 2009.

Bröndsted, J. (1938). Bronzealderens soldyrkelse. Gyldendal, Køpenhavn.

Evens, J. A., Chenary, C. A., \& Fitzpatrick, A. P. (2006). Bronze Age childhood migration of individuals near Stonehenge, revealed by strontium and oxygen isotope tooth enamel analysis. Archaeometry, 48(2), 309-321. http://dx.doi.org/10.1111/j.1475-4754.2006.00258.x

Kristensen, K. (2004). Långferder og hallristninger. Arkeologiska Skrifter, Göteborg.

Lind, B. G. (2004). Ales stenar ur ett arkeoastronomiskt perspektiv. Stjärnljusets förlag, p. 86.

Lind, B. G. (2012). Från Brantarör till Brantevik. Stjärnljusets förlag, p. 35. (with Geologisk Rapport by N. A. Mörner on p. 29-32).

Lind, B. G., \& Mörner, N. A. (2010). Mykenska och Feniciska spår på Österlen. Stjärnljusets förlag, p110.

Ling, J. (2012). Handel över haven 2000 år före vikingarna, Vetenskapsradion, June 12.

Marstrander, S. (1963). Östfolds jordbruksristniger i Skeberg. Oslo 1963.

Montelius, O. (1911). Solguden och hans dyrkan. Nordisk Tidskrift.

Mörner, N. A. (1999). Sea level and climate. Rapid regressions at local warm phases. Quaternary International, 60, 75-82. http://dx.doi.org/10.1016/S1040-6182(99)00008-7

Mörner, N. A. (2003). Paleoseismicity of Sweden - A novel paradigm. A contribution to INQUA from its Sub-commission on Paleoseismology, Reno. p. 320.

Mörner, N. A. (2011). Rapport över sommarens arkeologiska utgrävningar vid Ales Stenar. Del 2: Geologiska Arbeten. Rapport till RAÄ Länsstyrelsen i Skåne, p. 24.

Mörner, N. A. (2012a). Strict Solar Alignment of Bronze Age Rock Carvings in SE Sweden. Journal of Archaeological Science, 39, 3301-3305. http://dx.doi.org/10.1016/j.jas.2012.05.027

Mörner, N. A. (2012b). Paleoseismic fracturing of rock carvings 1000 BC in SE Sweden. 3rd INQUA-IGCP-567 International Workshop on Active Tectonics, Paleoseismology and Archaeoseismology, Morelia, Mexico, 19-24, Nov. 2012. INQUA-IGCP 567 Proceedings, 3, 127-130.

Mörner, N. A., \& Lind, B. (2008). A Mediterranean Bronze Age trading centre in SE Sweden? 33rd IGC, Oslo 2008, Abstract, IEA-01.

Mörner, N. A., \& Lind, B. G. (2010). A Mediterranean trading centre in southeast Sweden. In S. P. Paraminopoulos (Ed.), The Atlantis Hypothesis - Commentary 2008 (pp. 685-699). Heliotopos Publications.

Mörner, N. A., \& Lind, B. G. (2011). Long-distance travel and trading in the Bronze Age. Invited Poster, Atlantis 2011, 3rd International Conference, Santorini, June 2011. 
Mörner, N. A., \& Lind, B. G. (2012a). Long-distance travel and trading in the Bronze Age. In S. P. Paraminopoulos (Ed.), The Atlantis Hypothesis - Commentary 2011. Heliotopos Publications, in press.

Mörner, N. A., \& Lind, B. G. (2012b). Stonehenge has got a younger sister. Ales Stones decoded. International Journal of Astronomi and Astrophysics, 2(1), 23-27. http://dx.doi.org/10.4236/ijaa.2012.21004

Mörner, N. A., Lind, B. G., \& Possnert, G. (2009). Heimdall's Stones at Vitemölla in SE Sweden and the chronology and stratigraphy of the surroundings. Geografisla Annaler, 91A, 1-9.

Mörner, N. A., Jonsson, E., Ekerow, H., Henriksson, G., \& Lind, B. G. (2012). Utvärdering och Underkännande av RÄ̈ Rapport 2012:12 “Ales stenar: fördjupad kunskapsbas”. Strivelse till Länsstyrelsen i Skåne och RAÄ, $21 \mathrm{pp}$.

Nilsson, S. (1875). Spår efter feniciska kolonier i Skandinavien. Svenska Fornminnes-föreningens Tidskrift, Bd. $3,1-9$.

Strömberg, M. (1997). C14 - dateringar vid Ales stenar. Ale, 1, Lund.

Söderberg, B., Knarrström, A., \& Stark, K. (2012). Ales stenar: fördjupat kunskapsunderlag. RÄ̈, Rapport, 21, 134. 